\title{
22
}

\section{Reflections of a senior colleague}

\author{
John Nieuwenhuysen AM
}

It was a privilege and pleasure to be allowed to speak at the end of the remarkable conference, Engaging Indigenous Economy: Debating Diverse Approaches, and to offer a few reflections on the brilliant career of my friend, co-author and colleague of Melbourne University days, Professor Jon Altman.

Jon has worked on Indigenous development issues in Australia since 1976. He has made extremely important contributions which have been recognised in several ways, including a highly prestigious Australian Research Council (ARC) Professorial Fellowship and election as a Fellow of the Academy of Social Sciences in Australia. His role as foundation Director of the Centre for Aboriginal Economic Policy Research (CAEPR) at ANU between 1990 and 2010 has been inspiring and enormously productive. Jon has led the Centre by example and has combined the undoubted difficulties of gaining funds and ensuring the Centre's broad success with his own personal research, including many stints away from Canberra. In particular, Jon has worked for 30 years on 'People on Country' in the Top End, mainly in the Arnhem Land/Kakadu region.

Old men such as me are inclined to look back on their careers thinking of their mistakes and failures, of which there are many. But occasionally there is a bright moment in which a wise, even enlightened, action comes to the fore, and in my long working life, 
which lasted till the age of 75, there was one particular decision which proved extremely successful. That came in the mid-1970s when I was Chair of the Economics Department at the University of Melbourne, and we advertised a position of Senior Tutor. For this, an application was received by a then young man from the University of Auckland, Jon Altman. The department had a general rule that all applicants for positions should be seen in person. But, because Jon was outside Australia, a telephone interview was undertaken as a preliminary step. In the interview, Jon dazzled the committee with a rhetorically strong, clear, persuasive presentation. This was based on his fine, logical mind and wide knowledge and reading. And it led the committee to take the unprecedented decision to offer him the job without requiring his attendance at interview in person.

The decision proved an excellent one. Jon was a great tutor and a promising scholar. He had been at Melbourne less than a year when my own application for a grant of funds from the then Department of Aboriginal Affairs to do a study of the economic status of Aborigines succeeded. That grant was to finance a graduate research assistant for 1977, and I invited Jon to take the post. He did so, and as is often said, the rest is history. Jon worked assiduously and with great skill. He produced a manuscript that was completed in the year, and accepted for publication by Cambridge University Press. This 230-page volume, based on the 1971 Census, received considerable international notice and, 27 years later, in 2006, had an astonishing Cambridge reprint of the text as it stood.

After Melbourne, Jon went to ANU, where he undertook his PhD on hunter-gatherers in northern Australia - a thesis that was subsequently published as a book (Altman 1987).

From then on, Jon's publication list speaks for itself. It runs to over 30 pages, and totals nearly 400 items. The breadth of coverage is enormous, and the excellent annotation of the list by Annick Thomassin and Rose Butler (2014) is 109 pages long. In my many years of academic and research life, including a period on the ARC Panel on the Economic, Behavioural and Social Sciences Grants Committee, there are only a few scholars I have come across who can equal the inspirational imagination, volume, variety and quality of Jon's output. 
Happily, while Jon describes himself as an economic anthropologist, he has not trodden the path of the mainstream economics profession. As John Kenneth Galbraith explained, the prime criterion for admission to the apex in the hierarchy of the profession is that one should speak in a language so technical and complicated that no one outside the top echelon can comprehend it. By contrast, Jon's work has been directly related to policy. His independent research has made a striking and consistent contribution to knowledge and analysis, and he has been a tireless warrior in debate resting upon well-founded information.

Unlike some scholars who labour only in narrow, specialised segments of their discipline, Jon has ranged extremely broadly and is indeed a Renaissance man in Indigenous studies. Even the most casual glance at Jon's publications list will bear this out. Almost every facet of Indigenous studies in Australia has a place in Jon's encyclopaedic interest and productive output. The annotated list of his works is, as I have already mentioned, evidence of Jon's truly prodigious energy and commitment.

From my knowledge of Jon, three especially noteworthy aspects of his contribution deserve to be highlighted. The first is his involvement in Parliamentary Standing Committee proceedings. For example, on page 27 of Jon's publication list alone, there are seven items mentioning his submissions to Senate and House of Representative Standing Committees on a variety of important Indigenous affairs topics. Second are Jon's skills in linking scholars with business for ARC research projects. In one, the Committee for Economic Development of Australia (CEDA), of which I was then CEO, combined with Rio Tinto and CAEPR as partners to create a very generously funded and successfully completed project relating to mining and Indigenous employment. In this work, PhD theses were part of the design. Third is Jon's great popularity as a speaker. This capacity enabled him to maintain a strong image for the centre in a number of fields. For example, I recall listening to Jon deliver the Kenneth Myer lecture at the Melbourne Museum to a packed audience on the subject of Indigenous art. I may observe, however, that Jon's speech itself on that occasion was not all that excited every member of the audience. I was seated behind two attractive young women whose whispers as Jon spoke included interchanges on the possible extent to which Jon might 'pump iron', to use their phrase, and how it was that a university professor could look and sound so vibrant and virile. 
The Engaging Indigenous Economy Conference and this volume are a striking and well-deserved acknowledgement and celebration of Jon's wonderful contribution to Indigenous studies over nearly 40 years. In those decades, Jon has earned the right to declare, as Saint Paul did in his letter to his son Timothy, that he has fought the good fight and kept the faith. Jon's good fight has been for opportunity, equality and justice for Indigenous people in Australia. And he has waged this battle through keeping the faith for independent, fearless scholarly research that is exposed to a public debate in which Jon has been a persistently enlightened and reasonable but forceful voice. Jon is a man of scholarship, integrity, community, conscience and humanity. Australia, I believe, is a great beneficiary of his decision to come and work and live here.

A former New Zealand Prime Minister Mr Piggy Muldoon once famously said that the departure of New Zealanders to Australia raised the IQ of both countries. In Jon's case, his movement here was New Zealand's loss and Australia's gain.

Mr Muldoon also once said that Australia has 100 million sheep, 20 million of which considered themselves to be people. So we can only be grateful that Jon did not believe him.

I mentioned Saint Paul's reference to fighting the good fight and keeping the faith, and Jon's achievement of this. There was, however, a third part of his statement, namely that he had run his race to the finish. Many of us older folk rather like the quote that goes:

How nice it is to stand upon the shore and see the waves in wild commotion,

and enjoy it all the more because I am no longer on the ocean.

I do not think that Jon will align with that enjoyment. For I firmly believe that he still has an enormous amount of energy left in him and that - fortunately for Australia — Jon will continue his remarkable contribution for many years to come. So, we are all grateful for Jon's wonderful work and presence so far, and look forward to more to come. 


\section{References}

Altman JC (1987). Hunter-gatherers today: an Aboriginal economy in north Australia, Australian Institute of Aboriginal Studies, Canberra.

Thomassin A \& Butler R (2014). Engaging Indigenous economy: a selected annotated bibliography of Jon Altman's writings, 19792014, Working Paper 96, Centre for Aboriginal Economic Policy Research, The Australian National University, Canberra. 
This text is taken from Engaging Indigenous Economy: Debating diverse approaches, edited by Will Sanders, published 2016 by ANU Press, The Australian National University, Canberra, Australia. 